\title{
Natural Deep Eutectic Solvents as Sustainable Solvents for Suzuki-Miyaura Cross-Coupling Reactions Applied to Imidazo- Fused Heterocycles
}

\author{
Pierre-Olivier Delaye* \\ Mélanie Pénichon \\ Leslie Boudesocque-Delaye \\ Cécile Enguehard-Gueiffier \\ Alain Gueiffier
}

University of Tours, EA 7502 SIMBA, Faculty of Pharmacy, 31

Avenue Monge, Tours, France

pierre-olivier.delaye@univ-tours.fr

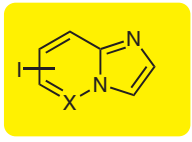

Biologicaly Relevant Imidazo-Fused Heterocycles
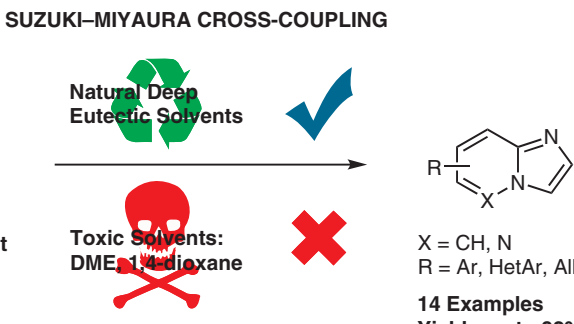

$\mathrm{X}=\mathrm{CH}, \mathrm{N}$ $\mathrm{R}=\mathrm{Ar}$, HetAr, Alk 14 Examples Yields up to $92 \%$
Received: 11.10.2018

Accepted after revision: 02.11.2018

Published online: 27.11 .2018

DOI: 10.1055/s-0037-1610400; Art ID: so-2018-d0054-op

License terms: cc)

Abstract Herein, we present the first Suzuki-Miyaura cross-coupling in a sustainable natural deep eutectic solvent (NaDES) applied to biologically relevant imidazo-fused scaffolds imidazo[1,2-a]pyridine and imidazo[1,2-b]pyridazine. The choline chloride/glycerol $(1: 2, \mathrm{~mol} / \mathrm{mol})$ $\mathrm{NaDES}$ allowed the functionalisation of diverse positions on the heterocycles with various boronic acids, by using $2.5 \mathrm{~mol} \%$ of readily available $\mathrm{Pd}(\mathrm{OAc})_{2}$. Notably, the catalytic system proceeds without any ligands or additives, without protection from the atmosphere.

Key words deep eutectic solvent, imidazopyridine, Suzuki-Miyaura coupling, sustainable chemistry

Imidazo-fused heterocycles, such as imidazo[1,2-a]pyridines and imidazo[1,2-b]pyridazines, have been widely exploited in various pharmacological areas because of their diverse biological activities. ${ }^{1}$ The imidazo[1,2-a]pyridine core can be found in marketed drugs such as the hypnotic Zolpidem or gastroprotective Zolimidine, while the imidazo[1,2-b]pyridazine core is a constituent of the anticancer drug Ponatinib (Figure 1).

As a result, there is a continued effort to design new methods for synthesis ${ }^{2}$ or functionalisation ${ }^{3}$ of such scaffolds. Our laboratory has contributed to the development of palladium-catalysed functionalisation of both imidazo[1,2$a]$ pyridines and imidazo $[1,2-b]$ pyridazines at diverse positions. ${ }^{4}$ In all cases, the reactions use organic solvents such as 1,2-dimethoxyethane (DME) or 1,4-dioxane. The search for alternatives to such organic solvents is a major concern, with the aim of developing safer, more environmentally acceptable reaction media. In recent decades, deep eutectic solvents (DES) have emerged as highly promising sustainable media for extraction of natural products, ${ }^{5}$ as well as for

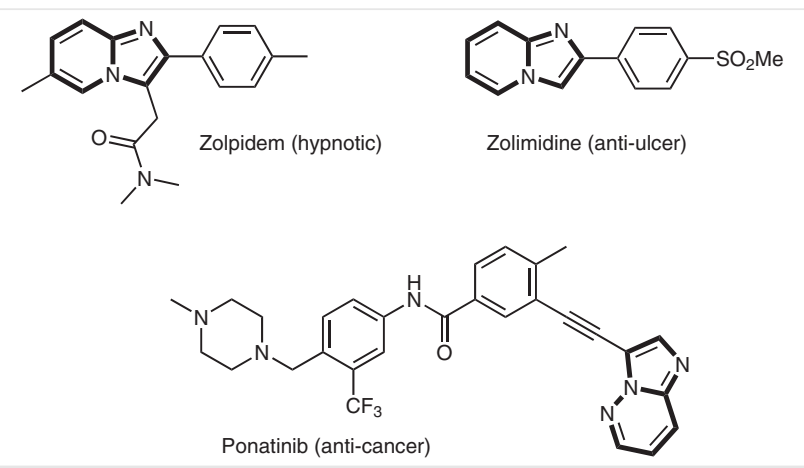

Figure 1 Structure of imidazo-fused heterocycle-containing marketed drugs Zolpidem ${ }^{\circledR}$, Zolimidine $^{\circledR}$, and Ponatinib ${ }^{\circledR}$.

organic chemical reactions. ${ }^{6}$ DES are mostly composed of a mixture of cheap, readily available and safe compounds, such as choline chloride, betaine, glycerol or a sugar, which are able to form a liquid phase at room temperature through hydrogen-bond-promoted self-association. DES have already found applications in the field of metal-catalysed organic reactions; ${ }^{7}$ especially palladium-catalysed cross-coupling, including Suzuki-Miyaura, ${ }^{8}$ Heck, ${ }^{9}$ Stille, ${ }^{10}$ Tsuji-Trost, ${ }^{11}$ Sonogashira ${ }^{9}$ and direct arylation via C-H activation. ${ }^{12}$ To date, all these conversions were demonstrated on 'model' substrates, such as biaryl synthesis using Suzuki-Miyaura conditions. ${ }^{8}$ Only very recently, Capriati et al. described four examples of the synthesis of heterocyclic products (indole, pyridine and thiophene structures) out of 34 biaryls produced. ${ }^{13}$ We present herein the first SuzukiMiyaura cross-coupling in DES applied to biologically relevant imidazo-fused scaffolds.

Optimization studies were performed on ethyl 3-iodoimidazo[1,2-a]pyridine-2-carboxylate $\mathbf{1 a}$, to determine the best catalyst (Table 1 ). Inspired by the work of Imperato et al., ${ }^{8 a}$ we began with phenylboronic acid in a low-melting 
mixture of mannose/dimethylurea (DMU) (3:7, w/w) in the presence of $20 \mathrm{~mol} \%$ of palladium catalyst and 1.25 equiv $\mathrm{Na}_{2} \mathrm{CO}_{3}$, overnight. From the five catalysts evaluated (entries 1-5), three were almost equally efficient: $\operatorname{Pd}(\mathrm{OAc})_{2}$, $\mathrm{PdCl}_{2}$, and $\mathrm{Pd}_{2}(\mathrm{dba})_{3}$. We therefore decided to continue the optimization process with $\mathrm{Pd}(\mathrm{OAc})_{2}$. Applying microwave irradiation to the reaction mixture at 90,80 or $70^{\circ} \mathrm{C}$ (entries $6-8$, not internal temperatures) negatively impacted the yield. The reaction was then repeated with a reduced catalyst loading, and yields remained good down to 2.5 mol\% catalyst (entry 11 ); with $1 \mathrm{~mol} \%$ the yield dropped to $76 \%$ (entry 12). Finally, we investigated the effect of reaction time. With $20 \mathrm{~mol} \% \mathrm{Pd}(\mathrm{OAc})_{2}$, full conversion, as assessed by TLC, could be attained in one hour, but with a lower yield of $66 \%$ (entry 13 ; compared with $78 \%$ after overnight heating: entry 1 ). Using $10 \mathrm{~mol} \%$ catalyst, three hours were needed to ensure full conversion, although resulting in a moderate isolated yield of $57 \%$. The optimal conditions were therefore taken as $2.5 \mathrm{~mol} \% \mathrm{Pd}(\mathrm{OAc})_{2}$, with conventional oil-bath heating to $90^{\circ} \mathrm{C}$ overnight. It is interesting to note that none of these conversions required additional ligands or other additives, and proceeded without need for an inert atmosphere.

Table 1 Optimization of the Catalyst

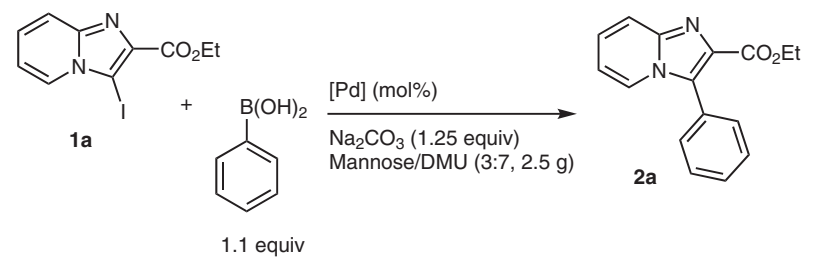

\begin{tabular}{lllll}
\hline Entry & {$[\mathrm{Pd}](\mathrm{mol} \%)$} & Temp. $\left({ }^{\circ} \mathrm{C}\right)$ & Time & ${\text { Yield }(\%)^{\mathrm{a}}}^{\circ}$ \\
\hline 1 & $\mathrm{Pd}(\mathrm{OAc})_{2}(20)$ & 90 & overnight & 78 \\
2 & $\mathrm{PdCl}_{2}(20)$ & 90 & overnight & 60 \\
3 & $\mathrm{PdCl}_{2}(\mathrm{dppf}) \cdot \mathrm{CH}_{2} \mathrm{Cl}_{2}(20)$ & 90 & overnight & 15 \\
4 & $\mathrm{Pd}_{2}(\mathrm{dba})_{3}(20)$ & 90 & overnight & 61 \\
5 & $\mathrm{PdCl}_{2}\left(\mathrm{PPh}_{3}\right)_{2}(20)$ & 90 & overnight & 30 \\
6 & $\mathrm{Pd}(\mathrm{OAc})_{2}(20)$ & $90^{\mathrm{c}}$ & 30 min & 31 \\
7 & $\mathrm{Pd}(\mathrm{OAc})_{2}(20)$ & $80^{\mathrm{c}}$ & 30 min & $30^{\mathrm{b}}$ \\
8 & $\mathrm{Pd}(\mathrm{OAc})_{2}(20)$ & $70^{\mathrm{c}}$ & 30 min & $30^{\mathrm{b}}$ \\
9 & $\mathrm{Pd}(\mathrm{OAc})_{2}(10)$ & 90 & overnight & 86 \\
10 & $\mathrm{Pd}(\mathrm{OAc})_{2}(5)$ & 90 & overnight & 84 \\
11 & $\mathrm{Pd}(\mathrm{OAc})_{2}(2.5)$ & 90 & overnight & 93 \\
12 & $\mathrm{Pd}(\mathrm{OAc})_{2}(1)$ & 90 & overnight & 76 \\
13 & $\mathrm{Pd}(\mathrm{OAc})_{2}(20)$ & 90 & $1 \mathrm{~h}$ & 66 \\
14 & $\mathrm{Pd}(\mathrm{OAc})_{2}(10)$ & 90 & $3 \mathrm{~h}$ & 57
\end{tabular}

a Isolated yields after column chromatography.

${ }^{b}$ Estimated yields of crude product by ${ }^{1} \mathrm{H}$ NMR spectroscopic analysis.

' Reaction performed under microwave irradiation.
With the optimum catalyst loading and reaction conditions established, a study to find the best solvent system was initiated (Table 2). Different low-melting solvents previously described by Imperato et al. in $2006^{10}$ and Ilgen et al. in 2009, ${ }^{9}$ were first screened (entries $1-3$ ). As previously noted in Table 1, the Mannose/DMU melt $(3: 7, \mathrm{w} / \mathrm{w})$ allowed the reaction to be completed cleanly in $93 \%$ isolated yield (Table 2, entry 1 ). Systems containing $\mathrm{NH}_{4} \mathrm{Cl}$ resulted in a total loss of reactivity, with the starting material being fully recovered (entries 2-3). We then tested various deep eutectic solvents (DES) available in the laboratory for the extraction of natural products, but lower yields were obtained; $42 \%$ for glycerol/glucose $(3: 1, \mathrm{~mol} / \mathrm{mol}$, entry 4$)$, $16 \%$ for choline chloride/glucose $(2: 3, \mathrm{~mol} / \mathrm{mol}$, entry 5$)$ and $32 \%$ for choline chloride/glucose $/ \mathrm{H}_{2} \mathrm{O}(2: 1: 3, \mathrm{~mol} / \mathrm{mol} / \mathrm{mol}$, entry 6$)$. Use of choline chloride/urea $(1: 2, \mathrm{~mol} / \mathrm{mol})$ did not result in any conversion, with starting material being fully recovered. Finally, we examined the choline chloride/glycerol $(1: 2, \mathrm{~mol} / \mathrm{mol})$ system used by Marset et al. in $2017^{8 b}$ and Massolo et al. in 2016, ${ }^{14}$ and desired product 2a was obtained in a good yield of $74 \%$. Using this DES, the reaction time could be decreased to $2 \mathrm{~h}$ (entry 8 ) or even $1 \mathrm{~h}$ (entry 9), with equivalent yields. This DES belongs to the class of NaDES (Natural Deep Eutectic Solvents), being composed of primary metabolites, ${ }^{15}$ and is fully user-friendly, easy to prepare in bulk and can be stored for months under ambient conditions.

Table 2 Optimization of the Low-Melting Solvent/DES<smiles>CCOc1nc2ccccn2c1I</smiles>

$1 a$<smiles></smiles>

(1.1 equiv)

\begin{tabular}{llll}
\hline Entry & Solvent & Time & Yield (\%) \\
\hline 1 & Mannose/DMU $(3: 7, \mathrm{w} / \mathrm{w})$ & overnight & $93^{\text {a }}$ \\
2 & D-sorbitol/DMU $/ \mathrm{NH}_{4} \mathrm{Cl}(7: 2: 1, \mathrm{w} / \mathrm{w})$ & overnight & 0 \\
3 & glucose/urea $/ \mathrm{NH}_{4} \mathrm{Cl}(6: 3: 1, \mathrm{w} / \mathrm{w})$ & overnight & 0 \\
4 & glycerol/glucose $(3: 1, \mathrm{~mol} / \mathrm{mol})$ & overnight & $42^{\text {a }}$ \\
5 & choline chloride/glucose $(2: 3, \mathrm{~mol} / \mathrm{mol})$ & overnight & $16^{\text {a }}$ \\
6 & choline chloride/glucose $/ \mathrm{H}_{2} \mathrm{O}(2: 1: 3$, & overnight & $32^{\text {a }}$ \\
& mol/mol/mol $)$ & & \\
7 & choline chloride/urea $(1: 2, \mathrm{~mol} / \mathrm{mol})$ & overnight & 0 \\
8 & choline chloride/glycerol $(1: 2, \mathrm{~mol} / \mathrm{mol})$ & overnight & $74^{\text {b }}$ \\
9 & choline chloride/glycerol $(1: 2, \mathrm{~mol} / \mathrm{mol})$ & $2 \mathrm{~h}$ & $71^{\text {a }}$ \\
10 & choline chloride/glycerol $(1: 2, \mathrm{~mol} / \mathrm{mol})$ & $1 \mathrm{~h}$ & $73^{\text {a }}$ \\
\hline
\end{tabular}

a Isolated yield

b Determined by HPLC. 
We then decided to explore the scope of the reaction toward different halogenated heterocycles (Table 3). For the first example 1b (entry 1) we tested the four best solvent systems from Table 2: mannose/DMU (3:7, w/w), glycerol/glucose $(3: 1, \mathrm{~mol} / \mathrm{mol})$, choline chloride/glucose $(2: 3$, $\mathrm{mol} / \mathrm{mol})$, choline chloride/glucose $/ \mathrm{H}_{2} \mathrm{O}$ (2:1:3, $\mathrm{mol} / \mathrm{mol} / \mathrm{mol}$ ) and choline chloride/glycerol $(1: 2, \mathrm{~mol} / \mathrm{mol})$. Contrary to observations with 1a, glycerol/glucose (3:1, $\mathrm{mol} / \mathrm{mol}$ ) was not effective with $\mathbf{1 b}$, as only starting material was recovered. Choline chloride/glucose $(2: 3, \mathrm{~mol} / \mathrm{mol})$ and choline chloride/glucose $/ \mathrm{H}_{2} \mathrm{O}(2: 1: 3, \mathrm{~mol} / \mathrm{mol} / \mathrm{mol})$ gave only low yields of 30 and 36\%, respectively. Mannose/DMU (3:7, w/w) and choline chloride/glycerol $(1: 2$, $\mathrm{mol} / \mathrm{mol}$ ) were the two best solvents for $\mathbf{1 b}$, with yields of 66 and $89 \%$, respectively, and a yield of $88 \%$ could be obtained with the latter system after one hour instead of overnight. We therefore chose to work with both mannose/DMU (3:7, w/w) and choline chloride/glycerol $(1: 2$, $\mathrm{mol} / \mathrm{mol}$ ). In the imidazo[1,2-a]pyridine series, 2-, 3-, 6- or 8-iodinated compounds could be functionalized with $\mathrm{PhB}(\mathrm{OH})_{2}$ (Table 3, entries 1-4 and 6-7). In all cases, NaDES choline chloride/glycerol $(1: 2, \mathrm{~mol} / \mathrm{mol})$ proved to be superior to mannose/DMU $(3: 7, \mathrm{w} / \mathrm{w})$, resulting in significantly higher yields. The reaction time required to end with full conversion strongly depended on the position of the iodosubstituent. In the 6 -position (entry 1 , compound $\mathbf{1 b}$ ), two

Table 3 Scope of the Suzuki-Miyaura Reaction using Various Halogenated Starting Materials
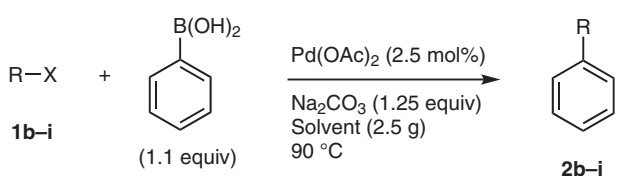

Entry

2

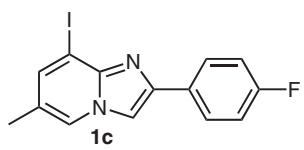

3<smiles>Ic1cn2ccccc2n1</smiles>

4

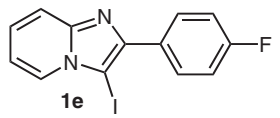

5

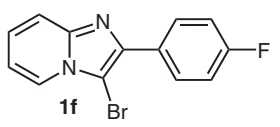

6

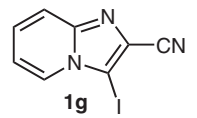

7<smiles>CCOC(=O)c1cn2cc(C)cc(I)c2n1</smiles>

8

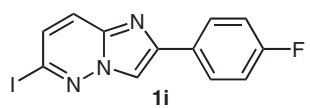

Solvent

mannose/DMU (3:7)

glycerol/glucose $(3: 1)$

choline chloride/glucose (2:3)

choline chloride/glucose $/ \mathrm{H}_{2} \mathrm{O}(2: 1: 3)$

choline chloride/glycerol (1:2)

mannose/DMU (3:7)

choline chloride/glycerol (1:2)

mannose/DMU (3:7)

choline chloride/glycerol (1:2)

mannose/DMU (3:7)

choline chloride/glycerol (1:2)

mannose/DMU (3:7)

choline chloride/glycerol (1:2)

mannose/DMU (3:7)

choline chloride/glycerol (1:2)

choline chloride/glycerol (1:2)

choline chloride/glycerol (1:2)
Time

overnight

overnight

overnight

overnight

overnight

$2 \mathrm{~h}$

overnight

$1 \mathrm{~h}$

$24 \mathrm{~h}$

overnight

overnight

$1 \mathrm{~h}$

overnight

overnight

overnight

overnight

$2^{a}$

traces

overnight

overnight

$1 \mathrm{~h}$

$74^{a}$
$82^{b}$

$6 \mathrm{~h}$

$59^{a}$

$1 \mathrm{~h}$

$89^{a}$ 
hours were enough to provide $88 \%$ of product $\mathbf{2 b}$, while the 8 -iodo-isomer 1c required $24 \mathrm{~h}$ to yield $69 \%$ of product $2 \mathrm{c}$ (entry 2). 2-Iodo- 1d was converted into $\mathbf{2 d}$ with overnight heating in a yield of $60 \%$ (entry 3 ); whereas one hour provided only $41 \%$ of $\mathbf{2 d}$ (entry 3 ). For the most commonly used 3-iodoimidazo[1,2-a]pyridines $\mathbf{1 a}, \mathbf{1 e}$ and $\mathbf{1 g}$, the reactivity strongly depends on the 2-substituent. As indicated previously, with an ester (compound 1a, Table 2, entry 9), one hour at $90{ }^{\circ} \mathrm{C}$ provided full conversion with a yield of $73 \%$. With the 2-(4-fluorophenyl) substrate (entry 4), the yield dropped to $45 \%$ after overnight heating; whereas with 2-cyano compound $\mathbf{1 g}$ (entry 6), one hour resulted in total conversion and a yield of $88 \%$. This effect of the 2-substituent was also observed for 8-iodo-substrate $\mathbf{1 h}$ (entry 7 ), for which $6 \mathrm{~h}$ of heating was sufficient to result in full consumption of starting material and a yield of 59\% (to be compared with entry 2 ).

We thus tried to evaluate the influence of the nature of the halogen with 3-brominated compound $1 \mathbf{f}$ (Table 3, entry 5 ). It was found that the bromide exhibited a radically different reactivity since virtually no product was isolated after heating overnight. Comparing this with the reactivity of 6 -iodoimidazo[1,2-b]pyridazine $\mathbf{1 i}$, we obtained a yield of $89 \%$ after one hour at $90{ }^{\circ} \mathrm{C}$ (entry 8 ).

Finally, we wished to extend our conditions to different boronic acids (Table 4). Imidazo[1,2-a]pyridine $\mathbf{1 a}$ and imidazo[1,2-b]pyridazine $1 \mathbf{i}$ were selected as substrates. Starting from 1a, electron-rich (entry 1) and electron-poor (entry 2 ) aryl boronic acids successfully providing products $\mathbf{3 a}$ and $\mathbf{3 b}$ in good yields of $78 \%(2 \mathrm{~h})$ and $88 \%(1 \mathrm{~h})$, respectively. Heteroaromatic 2-thienyl (entry 3 ) and methylboronic acids (entry 4) can also be used, but result in moderate yields of $34 \%(1 \mathrm{~h})$ and $29 \%(2 \mathrm{~h})$, respectively. Using imidazo[1,2-b]pyridazine $\mathbf{1 i}$, all aromatic boronic acids (entries $1-3$ ) resulted in high yields in no more than two hours, but methylboronic aicd (entry 4) did not lead to formation of methylated product.

The recycling of the catalyst was then investigated, with $1 \mathbf{i}$ as substrate. Our first attempts under our optimised conditions $\left(2.5 \% \mathrm{Pd}(\mathrm{OAc})_{2}, 1 \mathrm{~h}, 90^{\circ} \mathrm{C}\right)$ gave only moderate success with a drop in yield observed from the third cycle (data not shown). Thus, we decided to extend the reaction time for each cycle (ca. 6-7 h at $90^{\circ} \mathrm{C}$, Figure 2). After each cycle, product $2 \mathbf{i}$ was extracted from the DES with ethyl acetate, the DES was dried under vacuum, and then $1 \mathbf{i}, \mathrm{PhB}(\mathrm{OH})_{2}$ and $\mathrm{Na}_{2} \mathrm{CO}_{3}$ were added again for the next run. This modified protocol allowed recycling with identical efficiency over three cycles (run 1: $91 \%$, run 2: $86 \%$, run 3: $88 \%$ ), but then we observed a slow decrease in the yields (run 4: $78 \%$, run $5,72 \%$ ) to finally end with a significant drop in yield in the last recycling (run 6: 9\%). It is worth noting that the loss of yield might not correlate with a loss of catalytic activity, since a full completion was observed for all the runs, by TLC, even in the sixth. Thus, we postulate that this drop in isolated yield can be explained by increased difficulties in
Table 4 Scope of the Suzuki-Miyaura Reaction using Various Boronic Acids

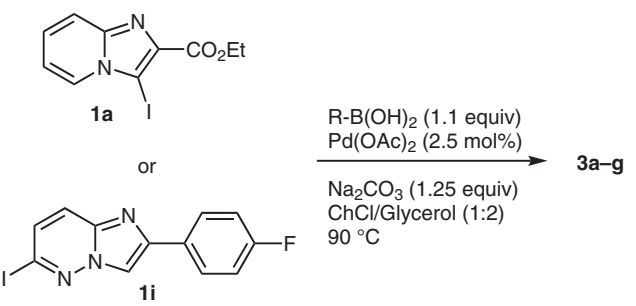

\begin{tabular}{lllll}
\hline Entry & $\mathrm{R}$ & Time (h) & $\begin{array}{l}\text { Yield (\%) } \\
\text { From 1a (Cpd) }\end{array}$ & From 1i (Cpd) \\
\hline 1 & 4- $\mathrm{CH}_{3} \mathrm{O}-\mathrm{Ph}$ & 2 & $78(\mathbf{3 a})$ & $90(\mathbf{3 e})$ \\
2 & $4-\mathrm{F}-\mathrm{Ph}$ & 1 & $88(\mathbf{3 b})$ & $92(\mathbf{3 f})$ \\
3 & Thien-2-yl & 1 & $34(\mathbf{3 c})$ & $82(\mathbf{3 g})$ \\
4 & methyl & 2 & $29(\mathbf{3 d})$ & 0 \\
\hline a Isolated yield. & & &
\end{tabular}

extracting the product from the DES over the cycles. Indeed, the DES became more viscous after each run, and finally became a slurry in run 6 . Improvement of the recycling process to overcome this limitation is under investigation in our laboratory.

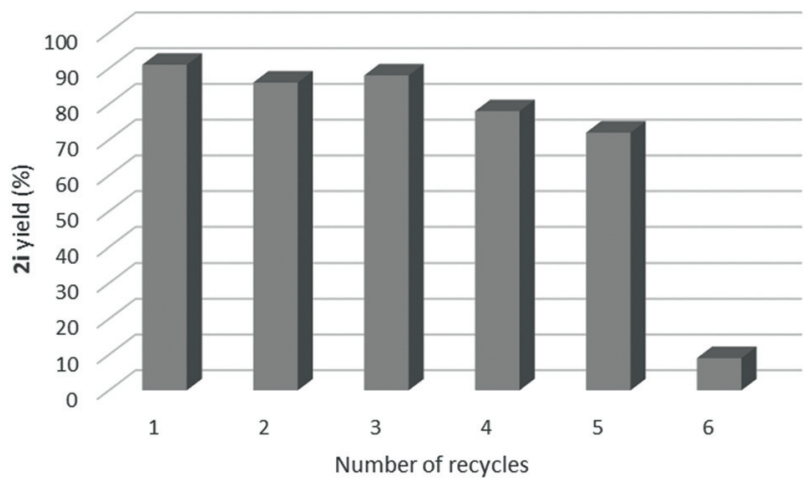

Figure 2 Recycling of $\mathrm{Pd}(\mathrm{OAC})_{2}$ in $\mathrm{ChCl} / \mathrm{Glycerol}(1: 2)$ for the synthesis of $\mathbf{2} \mathbf{i}$

To conclude, we report herein the first Suzuki-Miyaura cross-coupling in a natural deep eutectic solvent (NaDES) applied to imidazo-fused heterocycles of biological interest. Choline chloride/glycerol $(1: 2, \mathrm{~mol} / \mathrm{mol})$ was found to be the more general and efficient medium for coupling in both the imidazo[1,2-a]pyridine and imidazo[1,2-b]pyridazine series at diverse positions and with a variety of boronic acids. The reaction proceeded with $2.5 \mathrm{~mol} \% \mathrm{Pd}(\mathrm{OAc})_{2}$, without need for ligands, other additives or an inert atmosphere. This protocol represents a promising alternative to the organic solvents routinely used for such coupling (e.g., DME or 1,4-dioxane). In view of the importance of imidazofused heterocycles in medicinal chemistry, development of 
more ecologically friendly methods of pharmaco-modulation is urgently needed. The present protocol can be applied for recycling, over five cycles with good activity. Extension to other palladium-catalysed cross coupling (e.g., Sonogashira or Stille) is under investigation.

All reagents were used directly as obtained commercially. Thin-layer chromatography (TLC) was performed using Merk ${ }^{\circledR}$ silica gel $60 \mathrm{~F}_{254}$ plates. Column chromatography was performed using Merck Gedur$\mathrm{an}^{\circledR}$ Si $60(40-63 \mu \mathrm{m})$ silica. Melting points were determined with a Stuart capillary apparatus and are uncorrected. NMR spectra were recorded at $300 \mathrm{MHz}\left({ }^{1} \mathrm{H}\right)$ and $75 \mathrm{MHz}\left({ }^{13} \mathrm{C}\right)$ with a Bruker-Avance 300 $\mathrm{MHz}$ spectrometer. Assignment of carbons noted $\mathrm{C}^{*}$ may be interchanged. Microwave heating was performed using a CEM ${ }^{\circledR}$ Explorer SP $12 \mathrm{~S}$ class apparatus (max power $300 \mathrm{~W}$ ). Mass spectra were determined with a Hewlett Packard 5988A spectrometer or with a Shimadzu QP 2010 spectrometer by direct inlet at $70 \mathrm{eV}$. Compounds $\mathbf{2 a}{ }^{4 \mathrm{e}}$ $\mathbf{2 c},{ }^{16} \mathbf{2 d},{ }^{17} \mathbf{2 e},{ }^{4 \mathrm{e}} \mathbf{2 h},{ }^{16} \mathbf{2 i},{ }^{4 \mathrm{f}} \mathbf{3 a},{ }^{17} \mathbf{3 c},{ }^{4 \mathrm{e}} \mathbf{3 d},{ }^{4 \mathrm{e}} \mathbf{3 e},{ }^{4 \mathrm{f}} \mathbf{3 f},{ }^{4 \mathrm{f}}$ and $\mathbf{3} \mathbf{g}^{4 \mathrm{f}}$ are described in the literature, and all spectroscopic data were consistent with those previously described.

\section{Low-Melting and Deep Eutectic Solvents Preparation}

All the low-melting and deep eutectic solvents were prepared prior to use by heating the components together at $90{ }^{\circ} \mathrm{C}$ under vigorous stirring (magnetic stir bar) until a homogeneous solution was obtained (ca. 30-60 min). The reactions were performed in round-bottom test tubes $(9.5 \mathrm{~cm}$ high, $2.8 \mathrm{~cm}$ diameter) closed with a rubber septum, with $5 \mathrm{~g}$ of solvent per $1 \mathrm{mmol}$ of starting material. Only the choline chloride/glycerol $(1: 2, \mathrm{~mol} / \mathrm{mol})$ system was prepared on a larger scale $(80 \mathrm{~mL})$ and this was stored at r.t.

\section{Suzuki-Miyaura Coupling in Low-Melting Solvents and DES; Gen- eral Procedure}

Boronic acid (1.1 equiv), 1a-i ( 1 equiv, $1 \mathrm{mmol}$ ), $\mathrm{Na}_{2} \mathrm{CO}_{3}$ (1.25 equiv), and $\mathrm{Pd}(\mathrm{OAc})_{2}$ (2.5 mol\%) were successively added to the low-melting solvent or DES $(5 \mathrm{~g})$ at $90{ }^{\circ} \mathrm{C}$ (see above). The tube was closed with a rubber septum and the reaction mixture was stirred at $90^{\circ} \mathrm{C}$ until full conversion, as indicated by TLC (ca. $1-48 \mathrm{~h})$. The reaction mixture was cooled and water $(50 \mathrm{~mL})$ was added, followed by brine $(10 \mathrm{~mL})$. The reaction mixture was then extracted with EtOAc $(4 \times 35 \mathrm{~mL})$, the combined organic phases were dried over $\mathrm{MgSO}_{4}$, filtered, evaporated and the residue purified by column chromatography on silica gel (eluting with either petroleum ether/ethyl acetate or dichloromethane/ethyl acetate).

\section{Recycling Process; General Procedure}

Phenylboronic acid (1.1 equiv), $\mathbf{1 i}$ ( 1 equiv, $0.5 \mathrm{mmol}$ ), $\mathrm{Na}_{2} \mathrm{CO}_{3}(1.25$ equiv), and $\mathrm{Pd}(\mathrm{OAc})_{2}$ (2.5 mol\%) were successively added to DES (choline chloride/glycerol $1: 2,2.5 \mathrm{~g}$ ) at $90{ }^{\circ} \mathrm{C}$. The tube was closed with a rubber septum and the reaction mixture was stirred at $90{ }^{\circ} \mathrm{C}$ for 6 to $7 \mathrm{~h}$. The reaction mixture was cooled and extracted with EtOAc $(4 \times 20 \mathrm{~mL})$. The combined organic phases were dried over $\mathrm{MgSO}_{4}$, filtered, evaporated and purified by column chromatography on silica gel. The DES was then dried under vacuum for 15-30 minutes to remove all volatiles. Phenylboronic acid (1.1 equiv), $1 \mathbf{i}$ (1 equiv) and $\mathrm{Na}_{2} \mathrm{CO}_{3}$ (1.25 equiv) were then added and the next run repeated.

\section{2-(4-Fluorophenyl)-8-methyl-6-phenylimidazo[1,2-a]pyridine} (2b)

Yield: $133 \mathrm{mg}$ (89\%); white solid; $\mathrm{mp} 158-162{ }^{\circ} \mathrm{C}$.

${ }^{1} \mathrm{H} \mathrm{NMR}\left(300 \mathrm{MHz}, \mathrm{CDCl}_{3}\right): \delta=8.16$ (s, $\left.1 \mathrm{H}, \mathrm{H}-5\right), 7.99-7.93(\mathrm{~m}, 2 \mathrm{H}, 4-$ F-Ph-2,6), 7.83 (s, $1 \mathrm{H}, \mathrm{H}-3$ ), 7.58-7.55 (m, $2 \mathrm{H}, \mathrm{Ph}-2,6), 7.50-7.45$ (m, $2 \mathrm{H}, \mathrm{Ph}-3,5), 7.42-7.36$ ( $\mathrm{m}, 1 \mathrm{H}, \mathrm{Ph}-4), 7.24$ (s, $1 \mathrm{H}, \mathrm{H}-7), 7.17-7.09$ (m, $2 \mathrm{H}, 4-\mathrm{F}-\mathrm{Ph}-3,5), 2.71$ (s, $\left.3 \mathrm{H}, \mathrm{CH}_{3}\right)$.

${ }^{13} \mathrm{C}$ NMR $\left(75 \mathrm{MHz}, \mathrm{CDCl}_{3}\right): \delta=163.3\left(\mathrm{~d},{ }^{1} J_{\mathrm{C}-\mathrm{F}}=317.1 \mathrm{~Hz}, 4-\mathrm{F}-\mathrm{Ph}-4\right)$, 145.7 (C-8a*), $145.0\left(\mathrm{C}-2^{*}\right), 137.7$ (Ph-1), 130.4 (d, ${ }^{4} \mathrm{~J}_{\mathrm{C}-\mathrm{F}}=3.0 \mathrm{~Hz}, 4-\mathrm{F}-$ Ph-1), 129.2 (Ph-3,5), 128.0 (Ph-4*), 127.9 (4-F-Ph-2,6*), 127.4 (C-6), $127.0(\mathrm{Ph}-2,6), 124.5(\mathrm{C}-7), 120.8(\mathrm{C}-5), 115.7\left(\mathrm{~d},{ }^{2} J_{\mathrm{C}-\mathrm{F}}=21.6 \mathrm{~Hz}, 4-\mathrm{F}-\right.$ Ph-3,5), 108.8 (C-3), $17.4\left(\mathrm{CH}_{3}\right)$.

${ }^{19} \mathrm{~F}$ NMR $\left\{{ }^{1} \mathrm{H}\right\}\left(282 \mathrm{MHz}, \mathrm{CDCl}_{3}\right): \delta=-113.71$.

HRMS (ESI): $m / z[\mathrm{M}+\mathrm{H}]^{+}$calcd. for $\mathrm{C}_{20} \mathrm{H}_{15} \mathrm{FN}_{2}$ : 303.12920; found: 303.12699.

\section{3-Phenylimidazo[1,2-a]pyridine-2-carbonitrile (2g)}

Yield: $96 \mathrm{mg}$ (88\%); pale-yellow solid; $\mathrm{mp} 159-163^{\circ} \mathrm{C}$.

${ }^{1} \mathrm{H}$ NMR $\left(300 \mathrm{MHz}, \mathrm{CDCl}_{3}\right): \delta=8.24\left(\mathrm{dt},{ }^{3} J=7.2 \mathrm{~Hz},{ }^{4} J=0.9 \mathrm{~Hz}, 1 \mathrm{H}, \mathrm{H}-\right.$ 5), $7.68\left(\mathrm{dt},{ }^{3} J=9.3 \mathrm{~Hz},{ }^{4} J=0.9 \mathrm{~Hz}, 1 \mathrm{H}, \mathrm{H}-8\right), 7.65-7.51(\mathrm{~m}, 5 \mathrm{H}, \mathrm{Ph})$, 7.36 (ddd, $\left.{ }^{3} J=9.2,6.7 \mathrm{~Hz},{ }^{4} J=1.2 \mathrm{~Hz}, 1 \mathrm{H}, \mathrm{H}-7\right), 6.94\left(\mathrm{dt},{ }^{3} J=6.9 \mathrm{~Hz}\right.$, $\left.{ }^{4} \mathrm{~J}=1.1 \mathrm{~Hz}, 1 \mathrm{H}, \mathrm{H}-6\right)$.

${ }^{13} \mathrm{C}$ NMR $\left(75 \mathrm{MHz}, \mathrm{CDCl}_{3}\right.$ ): $\delta=145.5$ (C-9a), 132.6 (C-3), 130.3 (Ph-4), 129.8 (Ph-3,5), 129.0 (Ph-2,6), 127.2 (C-7), 125.9 (Ph-1), 124.0 (C-5), 119.0 (C-8), $116.5\left(\mathrm{C}-2^{*}\right), 115.3\left(\mathrm{CN}^{*}\right), 114.7$ (C-6).

HRMS (ESI): $m / z[M+H]^{+}$calcd. for $\mathrm{C}_{14} \mathrm{H}_{9} \mathrm{~N}_{3}$ : 220.08536; found: 220.08536 .

\section{Ethyl 3-(4-Fluorophenyl)imidazo[1,2-a]pyridine-2-carboxylate} (3b)

Yield: $125 \mathrm{mg}$ (88\%); pale-yellow solid; $\mathrm{mp} 151-155^{\circ} \mathrm{C}$

${ }^{1} \mathrm{H}$ NMR $\left(300 \mathrm{MHz}, \mathrm{CDCl}_{3}\right): \delta=7.90\left(\mathrm{~d},{ }^{3} J=7.0 \mathrm{~Hz}, 1 \mathrm{H}, \mathrm{H}-5\right), 7.74(\mathrm{~d}$, $\left.{ }^{3} J=9.2 \mathrm{~Hz}, 1 \mathrm{H}, \mathrm{H}-8\right), 7.53-7.47(\mathrm{~m}, 2 \mathrm{H}, 4-\mathrm{F}-\mathrm{Ph}-2,6), 7.32-7.22(\mathrm{~m}$, $3 \mathrm{H}, \mathrm{H}-7$ and 4-F-Ph-3,5), $6.84\left(\mathrm{dt},{ }^{3} \mathrm{~J}=6.9 \mathrm{~Hz},{ }^{4} \mathrm{~J}=1.0 \mathrm{~Hz}, 1 \mathrm{H}, \mathrm{H}-6\right)$, 4.35 (d, $\left.{ }^{3} \mathrm{~J}=7.1 \mathrm{~Hz}, 2 \mathrm{H}, \mathrm{CH}_{2} \mathrm{CH}_{3}\right), 1.31\left(\mathrm{t},{ }^{3} \mathrm{~J}=7.1 \mathrm{~Hz}, 3 \mathrm{H}, \mathrm{CH}_{2} \mathrm{CH}_{3}\right)$.

${ }^{13} \mathrm{C} \mathrm{NMR}\left(75 \mathrm{MHz}, \mathrm{CDCl}_{3}\right): \delta=163.5(\mathrm{CO}), 163.4\left(\mathrm{~d},{ }^{1} J_{\mathrm{C}-\mathrm{F}}=248.3 \mathrm{~Hz}, 4-\right.$ F-Ph-4), 144.5 (C-8a), 136.4 (4-F-Ph-1), 133.2 (C-2), 132.8 (d, ${ }^{3} \mathrm{~J}_{\mathrm{C}-\mathrm{F}}=$ $8.4 \mathrm{~Hz}, 4-\mathrm{F}-\mathrm{Ph}-2,6), 128.4$ (C-3), 126.5 (C-7), 124.0 (C-5), 119.2 (C-8), $116.2\left({ }^{2} J_{C-F}=21.9 \mathrm{~Hz}, 4-\mathrm{F}-\mathrm{Ph}-3,5\right), 114.0(\mathrm{C}-6), 61.2\left(\mathrm{CH}_{2} \mathrm{CH}_{3}\right), 14.4$ $\left(\mathrm{CH}_{2} \mathrm{CH}_{3}\right)$.

${ }^{19} \mathrm{~F}$ NMR $\left\{{ }^{1} \mathrm{H}\right\}\left(282 \mathrm{MHz}, \mathrm{CDCl}_{3}\right): \delta=-110.75$.

HRMS (ESI): $m / z[\mathrm{M}+\mathrm{H}]^{+}$calcd. for $\mathrm{C}_{16} \mathrm{H}_{14} \mathrm{FN}_{2} \mathrm{O}_{2}: 285.10338$; found: 285.10131.

\section{Supporting Information}

Supporting information for this article is available online at https://doi.org/10.1055/s-0037-1610332.

\section{References}

(1) (a) Enguehard-Gueiffier, C.; Gueiffier, A. Mini-Rev. Med. Chem. 2007, 7, 888. (b) Goel, R.; Luxami, V.; Paul, K. Curr. Top. Med. Chem. 2016, 16, 3590. (c) Deep, A.; Bhatia, R. K.; Kaur, R.; Kumar, S.; Jain, U. K.; Singh, H.; Batra, S.; Kaushik, D.; Deb, P. K. Curr. Top. Med. Chem. 2017, 17, 238. 
SynOpen

(2) Bagdi, A. K.; Santra, S.; Monir, K.; Hajra, A. Chem. Commun. 2015, 1555.

(3) Koubachi, J.; El Kazzouli, S.; Bousmina, M.; Guillaumet, G. Eur. J. Org. Chem. 2014, 5119.

(4) (a) Marie, E.; Boucle, S.; Enguehard-Gueiffier, C.; Gueiffier, A. Molecules 2012, 17, 10683. (b) Henry, N.; Enguehard-Gueiffier, C.; Théry, I.; Gueiffier, A. Eur. J. Org. Chem. 2008, 4824. (c) Enguehard-Gueiffier, C.; Croix, C.; Hervet, M.; Kazock, J.-Y.; Gueiffier, A.; Abarbri, M. Helv. Chim. Acta 2007, 90, 2349. (d) Enguehard, C.; Allouchi, H.; Gueiffier, A.; Buchwald, S. L. J. Org. Chem. 2003, 68, 4367. (e) Enguehard, C.; Renou, J.-L.; Collot, V.; Hervet, M.; Rault, S.; Gueiffier, A. J. Org. Chem. 2000, 65, 6572. (f) Enguehard, C.; Hervet, M.; Allouchi, H.; Debouzy, J.C.; Leger, J.-M.; Gueiffier, A. Synthesis 2001, 4, 595. (g) Enguehard, C.; Allouchi, H.; Gueiffier, A.; Buchwald, S. L. J. Org. Chem. 2003, 68, 5614.

(5) Zainal-Abidin, M. H.; Hayyan, M.; Hayya, A.; Jayakumar, N. S. Anal. Chim. Acta 2017, 979, 1.

(6) (a) Ruß, C.; König, B. Green Chem. 2012, 14, 2969. (b) Alonso, D. A.; Baeza, A.; Chinchilla, R.; Guillena, G.; Pastor, I. M.; Ramón, D. J. Eur. J. Org. Chem. 2016, 612.

(7) García-Álvarez, J. Eur. J. Inorg. Chem. 2015, 5147.
(8) (a) Imperato, G.; Höger, S.; Lenoir, D.; König, B. Green Chem. 2006, 8, 1051. (b) Marset, X.; Khoshnood, A.; Sotorríos, L.; Gómez-Bengoa, E.; Alonso, D. A.; Ramón, D. J. ChemCatChem 2017, 9, 1269.

(9) Ilgen, F.; König, B. Green Chem. 2009, 11, 848.

(10) Imperato, G.; Vasold, R.; König, B. Adv. Synth. Catal. 2006, 348, 2243.

(11) Jérôme, F.; Ferreira, M.; Bricout, H.; Menuel, S.; Monflier, E.; Tilloy, S. Green Chem. 2014, 16, 3876.

(12) Punzi, A.; Coppi, D. I.; Matera, S.; Capozzi, M. A. M.; Operamolla, A.; Ragni, R.; Badudri, F.; Farinola, G. M. Org. Lett. 2017, 19, 4754.

(13) Dilauro, G.; Garcia, S. M.; Tagarelli, D.; Vitale, P.; Perna, F. M.; Capriati, V. ChemSusChem 2018, 11, 1.

(14) Massolo, E.; Palmieri, S.; Benaglia, M.; Capriati, V.; Perna, F. M. Green Chem. 2016, 18, 792.

(15) (a) Dai, Y.; van Spronsen, J.; Witkamp, G.-J.; Verpoorte, R.; Choi, Y. H. Anal. Chim. Acta 2013, 766, 61. (b) Paiva, A.; Craveiro, R.; Aroso, I.; Martins, M.; Reis, R. L.; Duarte, A. R. C. ACS Sustainable Chem. Eng. 2014, 2, 1063.

(16) Kazock, J.-Y.; Enguehard-Gueiffier, C.; Théry, I.; Gueiffier, A. Bull. Chem. Soc. Jpn. 2005, 78, 154.

(17) Zeng, J.; Tan, Y. J.; Leow, M. L.; Liu, X.-W. Org. Lett. 2012, 14, 4386. 